[Bull. Agr. Chem. Soc. Japan, Vol. 21, No. 5, p. 329 331, 1957]

\title{
Infrared Spectrophotometric Determination of Traces of Parathion in Water
}

Sir :

In the previous communication "), two methods for the microdetermination of parathion in water (on a scale of $10 \gamma$ or less as the total amount) were presented. As the total amount of parathion treated in those methods is very small, it is difficult to perform the identification of parathion through infrared spectroscopy There is, however, a keen need for specificity in determination of parathion in sea and river water. Therefore, the third method which permits to carry out the infrared analysis, has been designed in order to establish more specific method for parathion determination. The Method 3. proposed for parathion determination is based on the solvent extraction, chromatography using heavy paper and infrared spectrophotometry. This method is also applicable to other insecticides illustrated in Table $\mathrm{I}$, and the sample can be treated on a scale of $100 \mathrm{mg}$ or more, if necessary.

Procedure: The steps of this method can be summarized as follows:

(1) Collection of parathion by liquid-liquid extraction. Parathion in the water sample

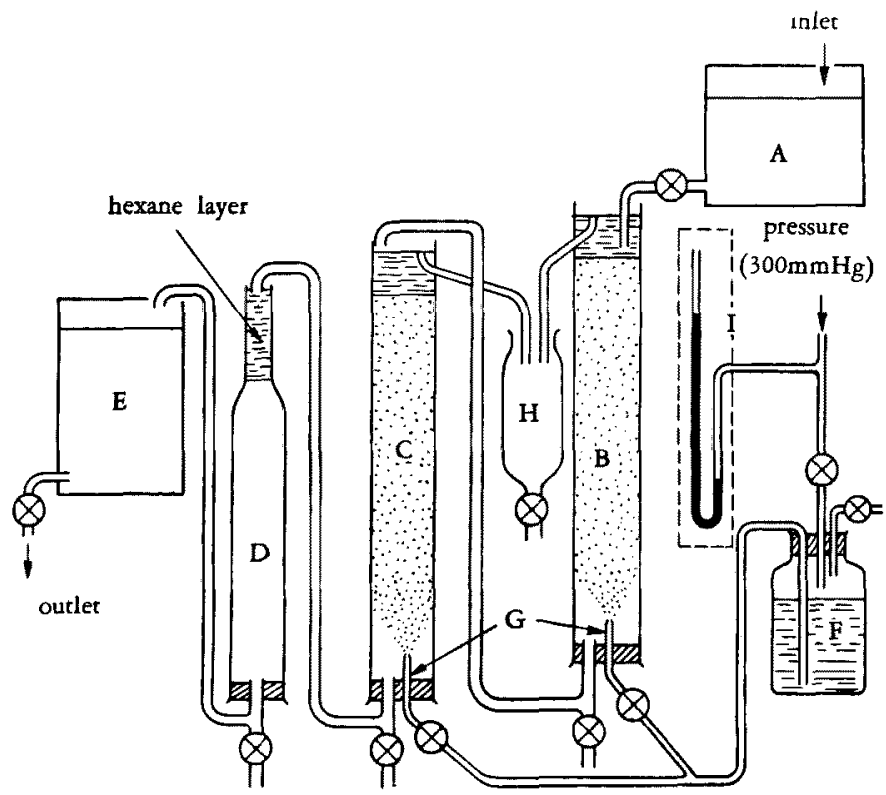

FIG. 1. Extractor for Liquid-Liquid System.

A. water sample tank; B \& C, extraction columa; D, separating column; E, separating tank; F, fresh solvent tank; $G$. nozzle; $H$. tank for extract layer; I, manometer.

1) Y. Sumiki, A. Matsuyama, H. Kato, Y. Chen and T. Yamauchi, Bull. Agr. Chem. Soc. Japan, 21, 204 (1957). can be quantitatively extracted into 2-4 1 of the solvent (equal volume mixture of 
TABle $1 . \quad R_{F}$ Values of Parathion and Related Compounds

Compound

\begin{tabular}{|c|c|c|c|}
\hline $\begin{array}{l}\text { Compound } \\
\text { (Mobile Solvent) }\end{array}$ & n-Hexane & Ethanol & $\begin{array}{c}\text { Ethanol-Nitromethane } \\
(4: 1 \mathrm{v} / \mathrm{v})\end{array}$ \\
\hline (Stationary Solvent) & $\begin{array}{l}\text { Ethylenechlorohydrine- } \\
\text { Methanol }(1: 1 \mathrm{v} / \mathrm{v})\end{array}$ & Soybean oil & Soybean oil \\
\hline Parathion & 0.23 & 0.56 & 0.53 \\
\hline Methylparathion & 0.10 & 0.65 & 0.63 \\
\hline 4124 (Isochlorthion) & 0.17 & 0.54 & 0.63 \\
\hline Ethyl 4124 & 0.36 & 0.45 & 0.41 \\
\hline Chlorthion & 0.13 & 0.56 & 0.50 \\
\hline Ethylchlorthion & 0.30 & 0.54 & 0.43 \\
\hline $\begin{array}{l}O \text {-(2-Nitrophenyl)-O,O- } \\
\text { diethylthiophosphate }\end{array}$ & $\begin{array}{l}(0.02),(0.06), 0.18 \\
0.32\end{array}$ & $0.60,0.81$ & $0.61,0.76$ \\
\hline EPN & 0.22 & 0.40 & 0.37 \\
\hline Dipterex & 0.02 & 0.79 & 0.81 \\
\hline Malathion & 0.12 & 0.69 & 0.75 \\
\hline TEPP, technical & $0,0.03$ & $0.71,0.75$ & $0.70,0.75$ \\
\hline Diaginon & 0.03 & 0.63 & 0.60 \\
\hline Systox, technical & $0.02,0.10$ & $(0.04),(0.64), 0.78$ & $(0.04),(0.64), 0.79$ \\
\hline Metasystox, technical & $0.02,0.04$ & 0.74 & $(0.02), 0.74$ \\
\hline Thimet, technical & $\begin{array}{l}(0.02),(0.11),(0.19) \\
0.75\end{array}$ & $0.56,(0.82)$ & $0.46,(0.80)$ \\
\hline Trithion, technical & $(0.01), 0.64$ & $(0.06), 0.28$ & $(0.08), 0.38,(0.86)$ \\
\hline DDVP, technical & $0,0.02,(0.05), 0.10$ & $0.05,0.82$ & $0.05,0.85$ \\
\hline$p, p^{\prime}-\mathrm{DDT}$ & 0.74 & 0.26 & 0.28 \\
\hline$\gamma-\mathrm{BHC}$ & 0.32 & 0.41 & 0.42 \\
\hline Orthophosphate & 0 & 0 & 0 \\
\hline Pyrophosphate & 0 & 0.01 & 0.02 \\
\hline
\end{tabular}

benzene and hexane) by passing 2001 of the water sample through the extractor at the rate of 100-120 1 per hour. The solvent is introduced from a nozzle as a spray and allowed to pass gently through the extraction column in countercurrent wise against the water sample flow. This extractor can be operated in the working field or on boats whtie electric or any other motive power is unavailable.

(2) Concentration of extracted layer. The removal of the solvent is carried out at first by the vacuum distillation apparatus with a long neck distillating flask till the volume of the solution comes to about $200 \mathrm{ml}$ and followed by carefull evaporation to oils using 2) J.A.A. Ketelaar and J.E. Hellingman, Anal. Cbem. 23. 646 (1951). an agitating evaporator ${ }^{1)}$. Ninety seven per cent of parathion can be recovered throughout the steps of extraction and concentration.

(3) Isolation by paper chromatography. Parathion in the extracts can be isolated from other insecticides by the paper chromatographic technique. Two separate chromatographic systems by descending method are employed in conjunction. The first uses soybean oil as a stationary solvent and either ethanol-nitromethane $(4: 1 \mathrm{v} / \mathrm{v})$ or ethanol only as a mobile solvent. This system mainly serves to separate parathion and EPN from each other. The second uses ethylenechlorohydrine methanol mixture $(1: 1 \mathrm{v} / \mathrm{v})$ as a stationary solvent and $n$-hexane as a mobile solvent. This system separates parathion from other insecticides except EPN. The spot of 


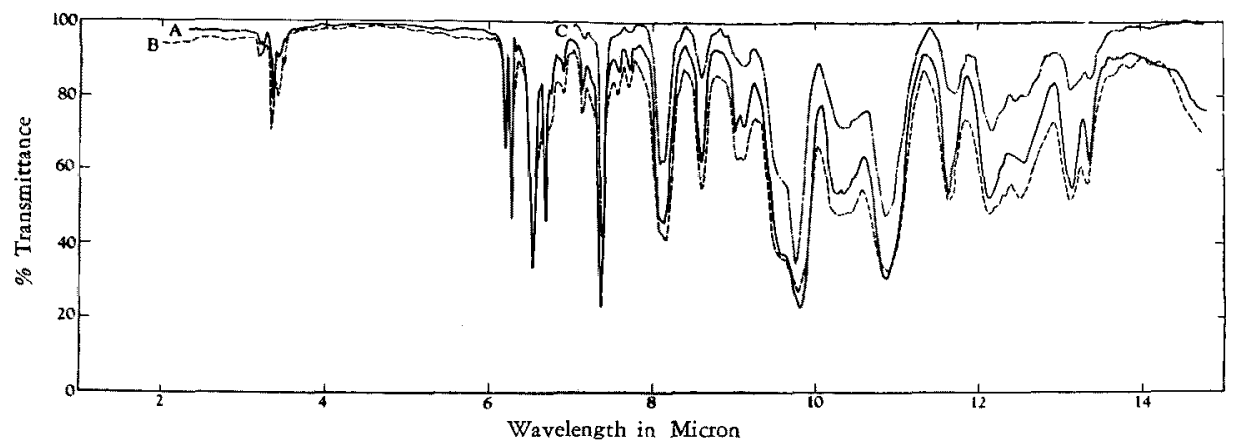

FIG. 2. Infrared Absorption Spectra of Parathion

A: Liquid film (unchromatographed) B: Liquid film (chromatographed) $C: 2 \%$ in $\mathrm{CS}_{2}, 0.1-\mathrm{mm}$. cell

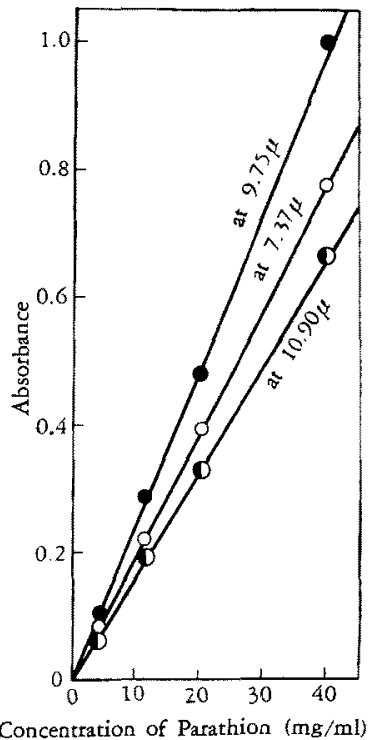

FIG. 3. Calibration Curve for Parathion in Carbon Disulfide Solution (in $0.1-\mathrm{mm}$ cell).

parathion can be detected by ultraviolet lamp irradiation under the guiding of its authentic sample. In this study the thicker paper (Toyo Roshi No. 27 for oil filter press) is used in order that the sample may be treated on a scale of $100 \mathrm{mg}$ or more. In the above chromatographic techique, further development of the paper chromatogram or liquid chromatography using a fraction collector can also be performed.

(4) Elution from paper chromatogram by ether
(5) Infrared spectrophotometry. A carbon disulfide solution can be used for qualitative identification in the 2- to 15 -micron region except the 6.2- to 7.0-micron region (thickness at $0.1 \mathrm{~mm}$.) and also for quantitative determination by measuring the absorption as 7.37 , 9.75 and 10.90 microns. If only qualitative examination is required, the spectrum may be obtained without dilution.

(6) Quantitative measurement of amounts of parathion. It is preferable that parathion is determined by means of several methods such as gravimetry and colorimetry of $p$ nitrophenate ion ${ }^{2,3)}$, azo dyel,4) and phosphorus1) in paralled with infrared analysis.

The recovery in the analysis of the wellwater sample by this presented method is 94\%. The experiments of the analysis of the sea and river water samples are at present under way. The authors wish to thank the National Institute of Agricultural Science, the Agricultural Chemical Inspection Station of the Ministry of Agriculture and Forestry, Sumitomo Chem. Ind. Co., Toa Agr. Chem. Co., Sankyo Co. for supplying the samples.

Yusuke Sumiki

Akira Matsuyama

Department of Agricultural Chemistry,

Faculty of Agriculture,

University of Tokyo.

$$
\text { Received August 5, } 1957
$$

4) P.R. Averell and M.V. Norris. Anal. Chem. 20, 753 (1948)

5) R.S. Bandurski, J. Biol. Chem., 193, 405 (1951).

6) L.C. Mitchel, J.A.O.A.C., 39, 891 (1956). 